\title{
Effect of follicular fluid NO, MDA and GSH levels on in vitro fertilization outcomes
}

Folikül sııısındaki NO, MDA ve GSH seviyelerinin in vitro fertilizasyon başarısına etkisi

\author{
Ender Yalçınkaya', Yiğit Çakıroğlu², Emek Doğer², Özcan Budak ${ }^{1}$, Mustafa Çekmen ${ }^{3}$ Eray Çalışkan² \\ 'IVF Center, Kocaeli University Faculty of Medicine, Kocaeli, Turkey \\ ${ }^{2}$ Department of Obstetrics and Gynecology, Kocaeli University Faculty of Medicine, Kocaeli, Turkey \\ ${ }^{3}$ Department of Biochemistry, Kocaeli University Faculty of Medicine, Kocaeli, Turkey
}

\section{Abstract}

Objective: To investigate the biochemical markers such as nitric oxide (NO), malondialdehyde (MDA) and reduced glutathione (GSH), indicators of the oxidative status of the follicle, to predict the outcome of in vitro fertilization.

Material and Methods: Follicular aspirates of dominant follicles were collected during oocyte retrieval. Biochemical analyses of NO, MDA and GSH were performed on all aspirates.

Results: When the successful and unsuccessful pregnancy groups were compared in terms of NO, MDA and GSH, follicular fluid MDA was significantly higher $(p=0.001)$ and follicular fluid NO level was significantly lower $(\mathrm{p}=0.039)$ in the pregnant group. Correlation analysis between oxidative stress and IVF parameters showed that MDA had a positive weak correlation with the number of grade 1 embryos $(\mathrm{r}=0.271, \mathrm{p}=0.033)$ and fertilization rate $(\mathrm{r}=0.263, \mathrm{p}=0.039)$. ROC curve analysis found that malondialdehyde has an area under the curve of 0.74 and can predict pregnancy with high sensitivity.

Conclusion: As malondialdehyde was significantly different in pregnant and non-pregnant women and had a good sensitivity profile in predicting pregnancy, it may be considered a marker for predicting IVF success. (J Turkish-German Gynecol Assoc 2013; 14: 136-41)

Key words: Follicular fluid, malondialdehyde, nitric oxide, glutathione, in vitro fertilization, pregnancy

Received: 22 April, 2013

Accepted: 21 May, 2013

\section{Özet}

Amaç: Folikül oksidatif durumunun belirteci olan nitrik oksit (NO), malondialdehit (MDA) ve redükte glutatyon (GSH) gibi kimyasal belirteçlerin in vitro fertilizasyon başarısına etkisinin araştırılması.

Gereç ve Yöntemler: Oosit toplama sırasında dominant foliküllerin aspire edilen sıvlanı toplandı. Tüm aspire edilen sıvılarda biyokimyasal analiz ile NO, MDA ve GSH seviyelerine bakıldı.

Bulgular: Gebelikle sonuçlanan ve gebe kalamayan olguların NO, MDA and GSH seviyeleri karşılaştırıldığında, folikül sıvısı MDA seviyesi gebe kalanlarda anlamlı olarak yüksek bulunurken $(p=0.001)$, NO seviyesi ise gebe kalanlarda anlamlı olarak düşük bulundu ( $\mathrm{p}=0.039)$. Oksidatif stres ve in vitro fertilizasyon parametreleri arasında korelasyon analizi yapıldığında, MDA ile grade 1 embriyo sayısı arasında $(\mathrm{r}=0.271, \mathrm{p}=0.033)$ ve fertilizasyon oranı arasinda $(\mathrm{r}=0.263, \mathrm{p}=0.039)$ zayıf pozitif bir korrelasyon bulundu. ROC eğrisi analizinde MDA'nın çizgi altında kalan alanı 0.74 hesaplanarak gebe kalan olguları öngörmede yüksek bir duyarlılığı olduğu bulundu.

Sonuç: Malondialdehit gebe kalan olguların follikül sıvllarında gebe kalamayanlardan anlamlı olarak yüksek bulunmasının yanı sıra, gebeliği öngörmede iyi bir duyarlılığa sahipti ve IVF olgularında gebeliği öngörmede bir belirteç olarak kullanılabilir.

(J Turkish-German Gynecol Assoc 2013; 14: 136-41)

Anahtar kelimeler: Folikül sıvısı, malondialdehit, nitrik oksit, glutatyon, in vitro fertilizasyon, gebelik

Geliş Tarihi: 22 Nisan 2013

Kabul Tarihi: 21 Mayıs 2013

\section{Introduction}

Infertility is defined as the inability to conceive for at least one year despite having regular sexual intercourse without using any contraception method. There are different causes of infertility. Nearly $40-50 \%$ of infertility problems are estimated to be of female origin and approximately $30 \%$ of cases are of male origin. A further $20-25 \%$ of couples suffer from unexplained factors (1). The pathophysiology of unexplained infertility is still a scientific question (2). In order to find some answers for unexplained cases, several investigators are trying to develop new, non-invasive biochemical markers that may affect gamete and embryo quality. Oxidative stress is being investigated as a causative marker in this manner. Studies on the pathophysiology of unexplained infertility have indicated that oxidative stress may be involved as an underlying factor $(3,4)$.

The maintenance of homeostasis in cells requires a complex interaction between prooxidants and antioxidants. Oxidative stress occurs as a result of a shift in this balance between prooxidants and antioxidants towards excess free radical formation (5). Oxidative stress affects all important components of cells, including lipids, proteins, carbohydrates and DNA. One of the most important harmful effects of free radical attack is the oxidation of unsaturated fatty acids, known as lipid peroxidation. One of the end products of lipid peroxidation 
is malondialdehyde (MDA). Since it is a stable end product, it can be used as a cumulative measure of lipid peroxidation (6). Nitric oxide (NO) is an inorganic, short-lived free radical gas that is synthesized from L-arginine via NO synthases. It has various physiological functions such as suppression of pathogens, vasodilatation and neurotransmission. It is a highly diffusible molecule and forms stable oxidized metabolites known as nitrites and nitrates (7). It has been reported that nitric oxide locally modulates granulosa cell function (8) and is involved in follicular maturation and ovulation in women $(9,10)$.

Evolutionarily, aerobic organisms have developed a biochemical defense system against the oxidative effects of reactive oxygen species. Thiol glutathione (GSH) functions as the most important endogenous antioxidant for the maintenance of the prooxidant-antioxidant balance in humans. GSH is a tripeptide containing a free sulfydryl group on a cysteine residue. It is found in high concentrations in the cytoplasm, nucleus and mitochondria (11). Oxidative stress is believed to affect reproductive functions (12). The effect of oxidative stress on the reproductive potential of men has been investigated extensively worldwide. However, there are limited reports about the possible effects on the female reproductive system (13-15).

Follicular fluid (FF) is the biological environment that supports the development of the oocyte and the subsequent embryo that is generated. It is a product of secretions of the granulosa and theca cells that surround the follicular wall. It may give perhaps the most important information about the effect of hormonal fluctuations which have an impact on oocytes. The composition of follicular fluid includes various substances such as cytokines, growth factors, antioxidants and vasoregulatory molecules. These mediators may a have direct effect on the maturation ability and the quality of oocytes (16).

The aim of this study was to investigate biochemical markers of oxidative stress such as NO and MDA and the antioxidant GSH in the follicular fluids of women undergoing ovarian hyperstimulation, intracytoplasmic sperm injection (ICSI) and embryo transfer, and to compare these parameters between two groups that were classified as successful pregnancy and unsuccessful pregnancy as an outcome of their assisted reproduction treatment.

\section{Materials and Methods}

\section{Subject selection}

Sixty-two infertile women aged between 25-32 years, who were admitted to the Kocaeli University IVF Unit and started to IVF treatment between September 2008 and October 2009, were included in this study. All of them had an etiology of unexplained infertility (no indication of a hormonal, ovulatory, tubal, uterine or sperm problem among the couples) and all were non-smokers. All of the subjects were free of any systemic disease (hypothyroidism, hyperthyroidism, diabetes, hyperprolactinemia) and had their first IVF treatment cycle. All of the women underwent ovulation induction with the long agonist $(\mathrm{N}=19)$, short antagonist $(\mathrm{N}=37)$ and microdose flare-up $(\mathrm{N}=6)$ protocols based on timing, hormonal conditions and ovarian reserve status of the women on the discretion of the clinician, followed by oocyte collection, ICSI and embryo transfer. ICSI was the preferred method for fertilization since it is associated with higher fertilization rates compared to conventional in vitro fertilization. Informed consent was obtained from each patient before participating in the study. Ethical approval was given by the Kocaeli University Ethics Committee.

\section{Sample collection and processing}

FF samples were taken from the dominant follicles of the patients during the oocyte pick-up procedure. No flushing was done during ovum pick-up in order to prevent culture media contamination. The samples were centrifuged at $2000 \mathrm{rpm}$ for 10 minutes, then the clean supernatants (free of erythrocytes) were aliquoted and stored at $-20^{\circ} \mathrm{C}$ for later use.

\section{MDA measurement}

Follicular fluid MDA measurement was done according to the protocol described by Ohkawa et al. (17). MDA reacts with thiobarbituric acid (TBA) to give a red compound which has a maximum absorbance at $532 \mathrm{~nm}$. TBA reagent was prepared by mixing $0.2 \mathrm{~mL}$ SDS (8.1\%), $1.5 \mathrm{~mL}$ acetic acid $(20 \%, \mathrm{pH}=3.5)$ and $1.5 \mathrm{~mL}$ TBA $(0.8 \%)$ together, then $0.2 \mathrm{~mL}$ of each thawed follicular fluid sample was mixed with this $3.2 \mathrm{~mL}$ TBA reagent and $0.8 \mathrm{~mL}$ distilled water. The mixture was incubated in a boiling water bath for $1 \mathrm{~h}$ and then cooled on ice.

After cooling, the mixture was mixed with $5 \mathrm{~mL} \mathrm{~N}$-butanol/ pyridine $(15: 1 \mathrm{v} / \mathrm{v})$ and $1 \mathrm{~mL}$ distilled water and centrifuged at $2500 \mathrm{rpm}$ for 5 minutes. The absorbance of the upper butanol phase was read at $532 \mathrm{~nm}$ against a blank and the results were calculated as $\mu \mathrm{M}$ MDA.

\section{GSH measurement}

Follicular liquid samples were supplemented with an equal volume of $5 \%(\mathrm{v} / \mathrm{v})$ metaphosphoric acid, and centrifuged at 3000 $\mathrm{g}$ for $10 \mathrm{~min}$ at $4^{\circ} \mathrm{C}$. GSH concentrations in the samples were measured by the method described by Yakubu et al. (18). The $\mathrm{GSH}$ concentrations in the samples are expressed as $\mu \mathrm{mol} / \mathrm{L}$.

\section{NO measurement}

Direct measurement of NO is difficult since it is an unstable product. NO was measured indirectly by measuring the total nitrite and nitrate concentration in the sample using the Griess method as described by Archer et al. (19). After deproteinization of the sample, all the nitrate in the sample was reduced to nitrite by incubation with cadmium. Afterwards, Griess reagent ( $1 \%$ sulfanylic acid $+0.1 \% \mathrm{~N}$-(1-naphtyl) ethylene diamine) was added into the sample and the absorbance was measured at $545 \mathrm{~nm}$. The NO concentrations are expressed as $\mu \mathrm{mol} / \mathrm{L}$.

\section{The collection of embryology laboratory data}

All the embryological data (number of oocytes retrieved, embryo quality, pregnancy status) were obtained from patient consultations and evaluation forms during the study. The embryo grading assessment was done according to fragmentation degree and blastomere size. Embryos with even blastomeres and $<10 \%$ fragmentation were categorized as grade A embryos, while those with even blastomeres and $<26 \%$ 
fragmentation (cell number 2 or 5 for day 2 OR 4 for day 2 and $\geq 9$ for day 3 ) and $11-25 \%$ fragmentation (cell number of 4 day 2 OR 4 for day 2 and 7-8 for day 3) were categorized as grade $\mathrm{B}$ embryos and with those uneven blastomeres and 26-35\% fragmentation were categorized as grade $\mathrm{C}$ embryos according to ASEBIR embryo assessment criteria (20). Grade D embryos were kept out of the statistical analysis. All women were transferred a single, grade A embryo on day 3 . Women who had a blood human chorionic gonadotropin level above $10 \mathrm{mIU} / \mathrm{mL}$ 12 days after embryo transfer were classified into the successful pregnancy group, while the others were considered the unsuccessful pregnancy group.

\section{Statistical Analysis}

SPSS version 13.0 was used for statistical analysis. Nonparametric Mann-Whitney U tests were used for group comparisons. The pregnancy status of women after IVF treatment was considered the primary outcome measure. Spearman correla- tion analysis was used for correlations. $\mathrm{p}<0.05$ was accepted as statistically significant.

\section{Results}

The mean ages of the patients in the successful pregnancy (Group 1) and unsuccessful pregnancy (Group 2) groups were $32.32 \pm 4.94$ and $31.42 \pm 3.53$, respectively $(p=0.898)$. IVF outcomes of the patients in both groups are given in Table 1. When the groups were compared in terms of the oxidative stress parameters shown in Table 2, statistically significant differences were found in FF MDA and FF NO levels $(p=0.001$ and $p=0.039$, respectively); however no significant difference was found between groups in terms of FF GSH $(p=0.076)$. Correlation analyses between oxidative stress and IVF parameters showed that MDA had a positive weak correlation with the number of grade A embryos $(\mathrm{r}=0.271, \mathrm{p}=0.033)$ and fertilization rate $(r=0.263, p=0.039)$ (Table 3$)$. ROC curve analysis revealed that

Table 1. IVF outcomes in both groups

\begin{tabular}{|l|c|c|c|}
\hline Outcome variables & $\begin{array}{c}\text { Group 1 } \\
(\mathbf{N = 2 7 )}\end{array}$ & $\begin{array}{c}\text { Group 2 } \\
\text { (N= 35) }\end{array}$ & p value \\
\hline \# of oocytes & $12.15 \pm 6.91$ & $11.83 \pm 9.66$ & 0.447 \\
\hline \# of mature oocytes & $9.30 \pm 5.71$ & $8.91 \pm 8.12$ & 0.381 \\
\hline Fertilization rate (\%) & $81.84 \pm 3.74$ & $70.77 \pm 4.86$ & 0.137 \\
\hline *Analyses were performed by the non-parametric Mann-Whitney U test. & \\
\hline
\end{tabular}

Table 2. Comparison of follicular fluid free radical and antioxidant GSH levels between groups

\begin{tabular}{|l|c|c|c|}
\hline & $\begin{array}{c}\text { Group 1 } \\
\mathbf{( N = 2 7 )}\end{array}$ & $\begin{array}{c}\text { Group 2 } \\
(\mathbf{N = 3 5 )}\end{array}$ & p value \\
\hline FF MDA $(\mu \mathrm{mol} / \mathrm{L})$ & $1.16 \pm 0.57$ & $0.70 \pm 0.49$ & 0.001 \\
\hline FF NO $(\mu \mathrm{mol} / \mathrm{L})$ & $33.67 \pm 12.23$ & $41.11 \pm 15.11$ & 0.039 \\
\hline FF GSH $(\mu \mathrm{mol} / \mathrm{L})$ & $8.21 \pm 5.32$ & $5.67 \pm 3.12$ & 0.076 \\
\hline *Analyses were performed by the non-parametric Mann-Whitney U test, NO: nitric oxide; MDA: malondialdehyde; GSH: glutathione
\end{tabular}

Table 3. Correlation between oxidative stress and IVF parameters

\begin{tabular}{|c|c|c|c|c|c|}
\hline & $\begin{array}{c}\text { \# of grade A } \\
\text { embryos }\end{array}$ & $\begin{array}{c}\text { \# of grade B } \\
\text { embryos }\end{array}$ & $\begin{array}{c}\text { \# of grade C } \\
\text { embryos }\end{array}$ & $\begin{array}{c}\text { Fertilization } \\
\text { rate }\end{array}$ & $\begin{array}{c}\text { \# of mature } \\
\text { embryos }\end{array}$ \\
\hline \multicolumn{6}{|c|}{ FF MDA } \\
\hline$r$ & 0.271 & -0.102 & -0.053 & 0.263 & -0.098 \\
\hline $\mathrm{p}$ & 0.033 & 0.430 & 0.680 & 0.039 & 0.450 \\
\hline \multicolumn{6}{|c|}{ FF NO } \\
\hline$r$ & -0.217 & 0.018 & 0.126 & -0.114 & -0.089 \\
\hline $\mathrm{p}$ & 0.091 & 0.892 & 0.328 & 0.378 & 0.492 \\
\hline \multicolumn{6}{|c|}{ FF GSH } \\
\hline$r$ & 0.086 & -0.050 & -0.018 & -0.102 & -0.004 \\
\hline $\mathrm{p}$ & 0.505 & 0.701 & 0.888 & 0.430 & 0.976 \\
\hline \multicolumn{6}{|c|}{$\begin{array}{l}\text { NO: nitric oxide; MDA: malondialdehyde; GSH: glutathione; } r \text { : Correlation coefficient; p: Significance } \\
\text { *Correlation analyses were performed by the Spearman correlation test }\end{array}$} \\
\hline
\end{tabular}


area under the curve for malondialdehyde was 0.74 for predicting pregnancy followed by glutathione $(\mathrm{AUC}=0.63)$ and nitric oxide $(\mathrm{AUC}=0.34)$ (Figure 1$)$. These data show that the level of nitric oxide is better at predicting unsuccessful pregnancy outcome.

\section{Discussion}

Follicular fluid is a very important microenvironment that plays a crucial role in the development of oocytes. The oocyte is maintained with the components of the follicular fluid while maturing. Therefore, it is highly possible that some biochemical characteristics of the follicular fluid play a critical role on oocyte quality and the subsequent potential to achieve fertilization and embryo development. The biochemical composition of follicular fluid includes proteins, sugars, reactive oxygen species, antioxidants and hormones. Moreover, the oxidant-antioxidant state of follicular fluid and its effects on oocyte and IVF outcomes has been of great interest in recent years (16).

Nitric oxide is an inorganic, free radical gas that has many physiological roles in folliculogenesis, ovulation and luteal function as well as in the cardiovascular, neurological and immune systems. Recent studies have demonstrated that nitric oxide is expressed by human granulosa cells and therefore present in significant amounts in human follicular fluid, and has also been detected in the follicular fluid after gonadotrophin stimulation. This suggests that this factor may be involved in the regulation of ovarian blood flow or in the maturation of human ovarian follicles (21). The observation that NO synthesis increases with follicle development showed that NO may have a role in regulating ovarian function. Rosselli et al. (22) found that increases in NO concentrations showed a correlation with increases in estrogen hormone levels. Moreover, Shukovski and Tsafriri (23)

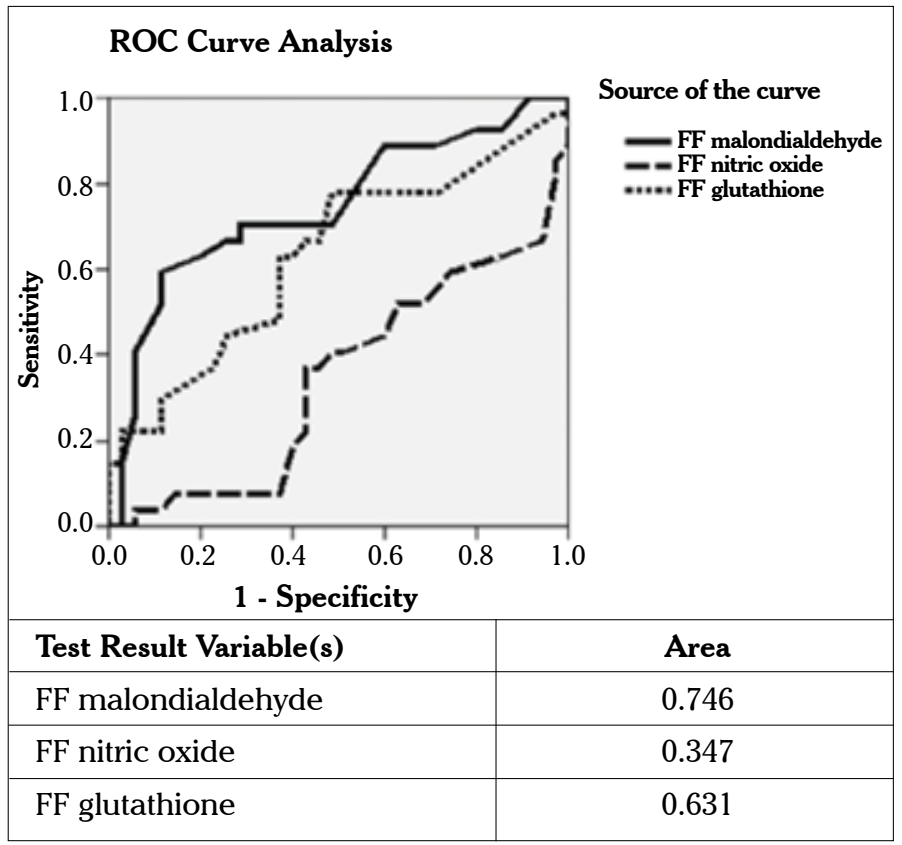

Figure 1. ROC curve analysis of follicular fluid malondialdehyde, glutathione and nitric oxide in predicting pregnancy outcome demonstrated that ovulation in rat was inhibited by the administration of NOS inhibitors, thus showing that NO participates in the ovulatory processes. Although these findings provide evidence about the role of NO in regulating ovarian function, it is still unclear if these effects are related to NO generated in the vasculature or generated by various cells in the ovary (24). The data on the impact of NO on IVF outcome are conflicting. Lee et al. (25) reported that nitrite/nitrate concentrations were significantly lower in the follicular fluid of mature oocytes, and higher fragmentation and lower implantation rates were observed in embryos exposed to high follicular fluid nitrite/ nitrate concentrations. In parallel, Barrionuevo et al. (26) showed that follicular $\mathrm{NO}_{3}{ }^{-} / \mathrm{NO}_{2}^{-}$levels have a strong inverse relationship with the fertilization potential of mature oocytes. In the light of these observations, at higher follicular fluid concentrations, NO is thought to be a good predictor of oocyte and embryo outcomes. Conversely, Manau et al. (27) suggested that NO assessments might be tricky since intrafollicular levels are not correlated with IVF outcomes.

Although the controlled generation of NO may have a physiological function as a signaling molecule, uncontrolled NO production may result in embryo toxicity $(2,5)$. The results of our study show that intrafollicular NO levels were significantly higher in the non-pregnant group compared to the pregnant group. However, when the relationship between NO and IVF parameters such as the number of mature oocytes, fertilization rate and embryo grading was assessed, no significant correlations were observed. Thus, we may conclude that high levels of NO may exert effects on pregnancy status through complex mechanisms of endometrial receptivity (implantation) or may have negative (toxic) effects on embryos that commits them to apoptosis before implantation.

When the deleterious effects of free radicals on cell integrity are considered, it is expected that there has to be a negative correlation between peroxidation levels and IVF outcomes; however, many studies have shown conflicting results in this respect. In a study by Appasamy et al. (28), it was found that follicular fluid ROS levels had a positive correlation with the pregnancy rate in IVF patients. This observation made researchers think that a limited amount of oxidative stress may be essential for embryonic development since it is an indicator of metabolic activity. The results of a study by Pasqualotto et al. (14) showed parallel results, as pregnant women after IVF treatment had higher lipid peroxidation (LPO) products compared to nonpregnant women. However, Oral et al. (12) found no significant relationship between follicular fluid malondialdehyde levels and fertilization rates. Accordingly, Jozwick et al. (29) reported no significant correlation between IVF outcome and different oxidative stress marker concentrations. On the contrary, in a study by Das et al. (30), it was observed that there was a negative correlation between ROS levels and embryo quality.

According to our results, we have found that there was a statistically significant difference in follicular fluid MDA levels between pregnant and non-pregnant women. The follicular fluid MDA levels in pregnant women were significantly higher than those in non-pregnant women. This might be explained by the weak positive correlation of MDA with the number of grade 
A embryos and fertilization rate, which are major predictors of successful IVF outcome. Our findings are in concordance with the results of Pasqualotto et al. (14), who found that pregnant women had higher lipid peroxidation levels. Agarwal et al. (2) also showed a positive correlation between pregnancy rates and lipid peroxidation.

In order to keep ROS levels in balance in the follicular fluid, it has been shown that the follicular fluid contains free radical scavengers to protect oocytes and embryos $(14,29)$. According to the results of some animal studies, oocyte GSH was shown to be important in decreasing disulfide bonds during sperm DNA decondensation and pronucleus formation, zygotic centrosome formation and pronucleus localization (31). In addition, GSH and GSH-forming blocks in oocyte and embryo culture media used in in vitro fertilization procedures have improved fertilization rates and embryo development (11).

Most of the studies relating the effect of GSH on oocyte and embryo quality in the literature have studied GSH content inside the cells $(31,32)$. There are few reports on the GSH content outside the cells, i.e. in follicular fluid, and its relationship with IVF outcome. In one of the studies about GSH content in follicular fluid, Liu et al. (33) found high GSH concentrations in the follicular fluids of small, medium and large sized follicles; however, there was no significant difference between different sizes in terms of GSH levels. They concluded that GSH in the follicular fluid may act as an anti-oxidant to protect oocytes from oxidation during oocyte growth and maturation. Ozkaya et al. (34) also studied the effect of multivitamin and mineral supplementation on GSH levels in the follicular fluid and serum of women with unexplained infertility in a recent study. However, in none of these studies were GSH levels in the follicular fluid correlated with IVF parameters and associated with IVF outcome.

In the present study, no significant correlation was found between follicular fluid GSH levels and fertilization rate and embryo quality. Also, there was no significant difference between pregnant and non-pregnant women in terms of follicular fluid GSH levels. This conclusion may reveal the inadequate efficiency of relatively low GSH levels in follicular fluid as an antioxidant compared to intracellular levels.

ROC curve analysis indicated that the follicular fluid malondialdehyde concentration is a good marker for pregnancy with an AUC of 0.746; glutathione and nitric oxide showed less sensitivity in estimating pregnancy status. This finding might be supported by the positive correlation of MDA with fertilization rate and the number of grade A embryos.

In order to eliminate any possible confounding effect related to age and the number of transferred embryos, the age range of women included in this study was kept very narrow (there was no statistically significant difference in age between the groups) and all were transferred a single, grade A, day 3 embryo. However, our study has some limitations. In our study, the follicular fluids taken from dominant follicles were evaluated as reflecting the entire ovary microenvironment. The oocytes from those follicles were not assessed independently. In this manner, further studies with a larger sample size are needed to perform individual and parametric analyses.

Ethics Committee Approval: Ethics committee approval was received for this study.
Informed Consent: Written informed consent was received from the participants of this study.

Peer-review: Externally peer-reviewed.

Author contributions: Concept - E.Y., E.Ç., M.Ç.; Design - E.Y., E.Ç.; Supervision - E.Y., E.C., M.C..; Resource - E.Y.; Materials E.Y.; Data Collection\&/or Processing - E.Y., E.Ç.; Analysis\&/or Interpretation - E.Y., E.C., Literature Search - E.Y.; Writing - E.Y, E.Ç.; Critical Reviews - E.Ç., Y.Ç.

Acknowledgements: The authors would like to thank Dr. Mert Musul for his technical support during preparation of the study.

Conflict of Interest: There is no conflict of interest declared by the authors.

Financial Disclosure: This study was financially supported by Kocaeli University Scientific Research Unit as a master thesis.

\section{References}

1. Duckitt K. Infertility and subfertility. Clin Evid 2003: 9; 2044-73.

2. Agarwal A, Gupta S, K Sharma R. Oxidative stress and its implications in female infertility- a clinician's perspective. Reprod Biomed 2005; 11; 641-50. [CrossRef]

3. Wang Y, Sharma RK, Falcone T, Goldberg J, Agarwal A. Importance of reactive oxygen species in the peritoneal fluid of women with endometriosis or idiopathic infertility. Fertil Steril 1997: 68; 826-30. [CrossRef]

4. Polak G, Koziol-Montewka M, Gogacz M, Blaszkowska I, Kotarski J. Total antioxidant status of peritoneal fluid in infertile women. Eur J Obstet Gynecol Reprod Biol 2001: 94; 261-3. [CrossRef]

5. Agarwal A, Said Tamer M, Bedaiwy Mohamed A, Banerjee J, Alvarez JG. Oxidative stress in an assisted reproductive techniques setting. Fertil Steril 2006: 86; 503-12. [CrossRef]

6. Oborna I, Wojewodka G, De Sanctis JB, Fingerova H, Svobodova $\mathrm{M}$, Brezinova $\mathrm{J}$, et al. Increased lipid peroxidation and abnormal fatty acid profiles in seminal and blood plasma of normozoospermic males from infertile couples. Hum Reprod 2010; 25: 308-16. [CrossRef]

7. Robbins RA, Grisham MB. Nitric oxide. The international journal of biochemistry \& cell biology 1997; 29: 857-60. [CrossRef]

8. Basini G, Baratta M, Ponderato N, Bussolati S, Tamanini C. Is nitric oxide an autocrine modulator of bovine granulosa cell function? Reprod Fertil Dev 1998; 10: 471-8. [CrossRef]

9. Anteby EY, Hurwitz A, Korach O, Revel A, Simon A, Finci-Yeheskel $\mathrm{Z}$, et al. Human follicular nitric oxide pathway: relationship to follicular size, oestradiol concentrations and ovarian blood flow. Hum Reprod 1996; 11: 1947-51. [CrossRef]

10. Tao M, Kodama H, Kagabu S, Fukuda J, Murata M, Shimizu Y, et al. Possible contribution of follicular interleukin-1 beta to nitric oxide generation in human pre-ovulatory follicles. Hum Reprod 1997; 12 : 2220-5. [CrossRef]

11. Ebisch IMW, Peters WHM, Thomas CMG, Wetzels AMM, Peer PGM, Steegers-Theunissen RPM. Homocysteine, glutathione and related thiols affect fertility parameters in the (sub)fertile couple. Hum Reprod 2006; 21: 1725-33. [CrossRef]

12. Oral O, Kutlu T, Aksoy E, Fiçıcıoğlu C, Uslu H, Tuğrul S. The effects of oxidative stress on outcomes of assisted reproductive techniques. J Assist Reprod Genet 2006; 23: 81-5. [CrossRef]

13. Oyawoye O, Abdel Gadir A, Garner A, Constantinovici N, Perrett C, Hardiman P. Antioxidants and reactive oxygen species in follicular fluid of women undergoing IVF: relationship to outcome. Hum Reprod 2003; 18: 2270-4. [CrossRef]

14. Pasqualotto EB, Agarwal A, Sharma RK, Izzo VM, Pinotti JA, Joshi 
$\mathrm{NJ}$ et al. Effect of oxidative stress in follicular fluid on the outcome assisted reproductive procedures. Fertil Steril 2004; 81: 973-6. [CrossRef]

15. Agarwal A, Aponte-Mellado A, Premkumar BJ, Shaman A, Gupta S. The Effects of Oxidative stress on female reproduction: a review. Reprod Biol Endocrinol 2012; 10: 49. [CrossRef]

16. Revelli A, Delle Piane L, Casano S, Molinari E, Massobrio M, Rinaudo P. Follicular fluid content and oocyte quality: from single biochemical markers to metabolomics. Reprod Biol Endocrinol. 2009; 7: 40. [CrossRef]

17. Ohkawa H, Ohishi N, Yagi K. Assay for lipid peroxides in animal tissues by thiobarbituric acid reaction. Anal Biochem 1979; 95: 351-8. [CrossRef]

18. Yakubu SI, Yakasai IA, Musa A. Spectrofluorimetric assay method for glutathione and glutathione transferase using monobromobimane. Journal of Basic and Clinical Pharmacy 2011; 2: 151-8.

19. Archer S. Measurement of nitric oxide in biological models. FASEB J 1993; 7: 349-60.

20. Alpha Scientists in Reproductive Medicine and ESHRE Special Interest Group of Embryology. The Istanbul consensus workshop on embryo assessment: proceedings of an expert meeting. Hum Reprod 2011; 26: 1270-83. [CrossRef]

21. Vignini A, Turi A, Giannubilo SR, Pescosolido D, Scognamiglio P, Zanconi S, et al. Follicular fluid nitric oxide (NO) concentrations in stimulated cycles: the relationship to embryo grading. Arch Gynecol Obstet 2008; 277: 229-32. [CrossRef]

22. Rosselli M, Imthurm B, Macas E, Keller PJ, Dubey RK. Circulating nitrite/nitrate levels increase with follicular development: indirect evidence for estradiol mediated NO release. Biochem Biophys Res Commun 1994; 202: 1543-52. [CrossRef]

23. Shukovski L, Tsafriri A. The involvement of nitric oxide in the ovulatory process in the rat. Endocrinology 1994; 135: 2287-90. [CrossRef]

24. Rosselli M, Keller PJ, Dubey RK. Role of nitric oxide in the biology, physiology and pathophysiology of reproduction. Hum Reprod Update 1998; 4: 3-24. [CrossRef]

25. Lee KS, Joo BS, Na JY, Yoon MS, Choi OH, Kim WW. Relationships between concentrations of tumor necrosis factor-alpha and nitric oxide in follicular fluid and oocyte quality. J Assist Reprod Genet 2000; 17: 222-8. [CrossRef]

26. Barrionuevo MJ, Schwandt RA, Rao PS, Graham LB, Maisel LP, Yeko TR. Nitric oxide (NO) and Interleukin-1 $\beta$ (IL-135) in Follicular Fluid and Their Correlation With Fertilization and Embryo Cleavage. AJRI 2000; 44: 359-64.

27. Manau D, Balasch J, Jimenez W, Fabregues F, Civico S, Casamitjana $\mathrm{R}$, et al. Follicular fluid concentrations of adrenomedullin, vascular endothelial growth factor and nitric oxide in IVF cycles: relationship to ovarian response. Hum Reprod 2000; 15: 1295-9. [CrossRef]

28. Appasamy M, Jauniaux E, Serhal P, Al-Qahtani A, Groome NP, Muttukrishna A. Evaluation of the relationship between follicular fluid oxidative stress, ovarian hormones, and response to gonadotropin stimulation. Fertil Steril 2008; 89: 912-21. [CrossRef]

29. Jozwik M, Wolczynski S, Jozwik M, Szamatowicz M. Oxidative stress markers in preovulatory follicular fluid in humans. Mol Hum Reprod 1999; 5: 409-13. [CrossRef]

30. Das S, Chattopadhyay R, Ghosh S, Goswami SK, Chakravarty $\mathrm{BN}$, Chaudhury K. Reactive oxygen species level in follicular fluid-embryo quality marker in IVF? Hum Reprod 2006; 21: 2403-7. [CrossRef]

31. Yoshida M, Ishigaki K, Nagai T, Chikyu M, Pursel VG. Glutathione concentration during maturation and after fertilization in pig oocytes: relevance to the ability of oocytes to form male pronucleus. Biol Reprod 1993; 49: 89-94. [CrossRef]

32. Gardiner CS, Reed DJ. Status of glutathione during oxidant-induced oxidative stress in the preimplantation mouse embryo. Biol Reprod 51, 1307-14. Griffith OW. (1980) Determination of Glutathione and Glutathione Disulfide Using Glutathione Reductase and 2-Vinylpyridine. Analytical Biochemistry 1994; 106: 207-212.

33. Liu RH, Li YH, Jiao LH, Wang XN, Wang H, Wang WH. Extracellular and intracellular factors affecting nuclear and cytoplasmic maturation of porcine oocytes collected from different sizes of follicles. Zygote 2002; 10: 253-60. [CrossRef]

34. Ozkaya MO, Nazıroğlu M. Multivitamin and mineral supplementation modulates oxidative stress and antioxidant vitamin levels in serum and follicular fluid of women undergoing in vitro fertilization. Fertil Steril 2010; 94: 2465-6. [CrossRef] 